\title{
GAJDA AND ZURNA OH THE BALKANS: DEVELOPMENT OF DIFFERENCES INSIDE NATIONAL BORDERS
}

\begin{abstract}
Listening to recordings of gajda and zurna in Greece, in North Macedonia, in Bulgaria and in the rest of the Balkans (wherever they exist), even in Turkey, one is surprised by the differences, especially if one takes into account the fact that most of these regions were a borderless part of Ottoman Empire till the early $20^{\text {th }}$ century. If one considers the similar linguistic phenomena, where national languages are adaptations of a "linguistic continuum", then one should come to the conclusion that the various national music traditions are adaptations of a similar "musical continuum" which earlier was not divided by such borders. In this case, what is the role of the folklorists? Do they just write down or are they essentially shaping the so-called traditions by applying their criteria? The presentation will try to shed some light to such questions (and, obviously, to put even more questions) focused on case studies.
\end{abstract}

Keywords: Gajda, Zurna, Greece, Discography, Nation.

Let me make it clear from the very beginning. My paper aims just to put some questions, with no perspective of answering them. Furthermore, the integrity and adequateness of the data I used must also be kept under investigation, as I will try to show. But I would say that when we are able to put clearly a question, we are already halfway to the answer.

So, let's start with a fundamental observation. Gajdas and zurnas sound pretty different in the various countries of the Balkans. There are zones where these instruments have an elaborate, refined sound, accurate in tune and in rhythm (e.g. in Bulgaria), while there are other regions where they sound totally primitive, as if they come out of a distant past (e.g. in Greece). Furthermore, while these instruments must once have been widespread everywhere, today there are regions where they have totally disappeared, leaving no trace at all. If these observations are true, then we have to ask, why? The Balkan peninsula has a more or less common history and a generally uniform geomorphology, if seen from some distance. Considering this very morphology, one should expect to find more differences inside a country like Greece, with its mountains, plains and islands as well, more than the differences that can be found, let's say, on the two sides of the national border that divides Greece from Bulgaria or North Macedonia. But this is not the case.

1.

I would like to make clear from the very beginning that I will base my research on recordings and discography. My experience comes mainly from records and tapes, not from live performances, and, frankly speaking, it's not equally detailed all over the various Balkan regions. It is the first question I would like to 
ask - is the recorded music identical to the performed music? This is a very broad issue, and the answer is in most cases "no". This "no" becomes particularly strong if we talk about ethnographic publications. The recording is somehow like a photograph. What comes out when a record is played does not totally coincide, and sometimes it does not coincide at all, with how the music really sounds in the villages and in the countryside, if we suppose that this is its natural locus. What comes to be published in discography passes essentially through two possible channels: one is the well-known commercial discography, which is motivated by the financial potential of popularity, while the other is the academic, "folkloristic" discography, where the criteria is, at least nominally, based on research and similar processes, as e.g. preservation or rescuing. In both cases, the decisions formulating the final discographic result are not taken in the "village", if we could put it like this, but in the city; record companies are located there, village musicians go there in order to get recorded, the decisions that give shape to the result are taken there. The audience from the "village" for sure influences the result, though from a distance, by a potentially buying public, while the population which moves between the village and the city also has a strong role of this kind, introducing elements of both sides to the final aesthetic. Of course, the village public is not uniform, neither it is one-dimensional; people love what sounds familiar, but they also love what is new, and novelties that come from the city frequently create poles of attraction. Observations, similar to those about the record company, are valid for the folklorist as well; he is recording in the village, but he resides in the city and most of the times his work is financed by some state budget and not by the local population; furthermore, his recordings and his publications are addressed to an urban public, frequently intellectual and small in size, which, in total contrast with the village public, considers age to be an advantage and not a deficiency, the way it happens with museum artifacts. These questions about the working ways (of folklorists but also of the commercial record industry), their advantages and disadvantages, have been discussed extensively the last decades, especially by scholars of social anthropology (Bohlman, 1988; Sterne, 2003; for the Greek territory, Mazaraki, 1984, 57-58).

In any case, we must take as granted that discography interacts with the musical universe of the village; this happened already in the gramophone years and goes on today and it happens not only with the commercial, but also with the folklore discography (and this is a detail that didn't become clear to the researchers from the very beginning). The musician of the village, as well as the "general public", listens to not only commercial recordings, but frequently ethnographic ones as well; speaking from my experience, I have come many times across village musicians who played material they found in ethnographic publications. Material from discography returns to the village, creating rules and norms about what is correct, what is beautiful, what should be preferred and thus shaping the evolution of the tradition. As Deltsou (1995) makes clear, the village is not a closed system, not even when it seems to be isolated on mountains or on islands; there has always been an exchange of information, and James Clifford's (1997) observation about "routes and not roots" is proven to be more and more correct. The villager frequently visits the city, and a significant percentage of village inhabitants split its 
time between the two. More often than not, even the village musician becomes a permanent city dweller, with only temporary expeditions to his village (mainly in the summer), as the financial life of the community has been transferred to the urban center.

\section{2.}

How are all of these general observations applied in the case of zurna and gajda on the Balkans? In the mid-war years, we had only a handful of recordings with gajda or zurna; in Greece, the oldest are most probably the ones made by Melpo Merlier, ${ }^{1}$ with refugee musicians from the Black Sea coast, in 1930, which was given to the public only four decades later (see Dragoumis, 1976; Dragoumis, 2003). I would like to put it as a main question, whether there was some kind of appreciation for zurna and gajda in the mid-war years, all over the Balkans. Speaking of Greece, in Thessaly e.g. or in Epirus, we find no gajdas, and zurna is met rather sparsely, getting the totally disrespect of local literati. Clarinet, according to all the available sources (mainly Despina Mazaraki, 1984) seems to be dominant from the late 19 century on, with very few exceptions in regions like Messolonghi. A somehow unexpected finding is that the infusion of the clarinet in the region is not affected by the changes of the state borders, as the Greek state expands gradually to the north and the east, against the Ottoman Empire. Greeks and Turks and all the ethnicities that inhabit the region welcome the advent of the clarinet as progress. It seems that the zurna and, mainly, the gajda, remained in use only in those regions where it was impossible for them to get substituted, mainly as a result of economic recession. Similar is the image we find in Albania, Romania, Serbia (including at that time the territory of North Macedonia), even in Bulgaria; gajdas and zurnas are rare, or totally absent from discography. It seems that the discographic landscape of the mid-war years is rather common in all the Balkan countries regarding the instruments at hand and it's shaped mainly by an intention to "improve" the village music, an intention reflecting the opinion of the village dwellers all over the world, or at least of a very big percentage of them. In case studies in Greece, we have striking information about this approach (including explicit proclamations of these instruments as cacophonous or even officially forbidden (Liapis, 1994, 174). The unpublished recordings of the folklorists, as far as I know, also show a restricted interest on zurnas and gajdas.

In fact, in Greece, musical folklore (as a practice of recordings in situ) was hardly developed before the advent of the tape recorder, in the 1950's. As of the recordings made after 1950, a lot of material has been published from some particular collections (Melpo Merlier's Musical Folklore Archive, Simon Karas' Society for Dissemination of National Music, Lyceum Club of Greek Women, Dora Stratou Theatre etc.), while from others, as from the voluminous archive of the

\footnotetext{
${ }^{1}$ Melpo Logothetis-Merlier (1889-1979) is credited with the first systematic collection (in sound) of Greek folk songs in 1930. Her "Society of Folk songs", subsidized by the then Venizelos government, became the basis of the Greek Musical Folklore Archive, which is active till today. Further info can be found at: http://www.mla.gr/.
} 
Athens Academy, only some few samples have been given to the public. A small number of recordings from Romania has been published too (mainly material from the mid-war years from the Constantine Brailoiu collection published in Switzerland). A small but informative collection of old Albanian local recordings was published also in Austria recently some years ago (Ahmedaya, 2012); the publication of ethnographic material abroad has been rather the norm, including the Alan Lomax collection, UNESCO, OCORA, Le Musee de l'homme and such similar non-profit organizations. I am not aware whether ethnographic material from the other countries has been published locally somehow.

Before going on to the post war years, I would like to talk a little about the work of folklorists in the first half of the 20 century. Folklorists, all over the Balkans (and not only there) and with rare exceptions, felt that their duty was to contribute to the national narratives. A big part of their activity was oriented to the separation of the things considered national, in each state, against those considered foreign. Languages have been also treated in similar ways, and in this way, we ended up in clearly defined national languages out of continuums of local dialects. The concept of the nation is the strongest motivation of those times. It is worth mentioning that earlier conceptions about the nation focused on the common religion (what was called millet in the Ottoman times), latterly incorporating also the language criterion, while today social anthropologists conceive the nation as an imaginary community (Anderson, 2006); one could simply brief Anderson's groundbreaking essay as "each nation consists of those who believe they belong to it". Language communities (in Ottoman times but also later), while frequently regarded today as communities of common origin, are proven to be connected with social classes rather than common origins (Roudometof, 1998).

Speaking of Greece, all scientists from the mid-19 century on, historians, philologists, folklorists etc., felt as their duty to prove the "continuity of the nation" from the antiquity till their present times and mainly to refute the theories of JacobPhilip Fallmerayer (who disputed totally the relation of the present day Greeks with their ancient ancestors, speaking about the settlement of the Greek peninsula by Slavic and Albanian people); their efforts have been studied in detail (Herzfeld, 1982). The conditions in late 19 and early 20 century (when the Greek state expanded and the formulation of the rest of the Balkan nation-states) intensified these efforts, and this continued in the mid-war years, when the Greek state had annexed lands where the Slavic languages were dominant. Soon not only language but also music left the sphere of scientific discussions and entered the sphere of state oppression (Divani, 1995, 298-370; Kostopoulos, 2008; Empeirikos et al., 2001, 143-276).

\section{3.}

Political proceedings after Second World War marked a change in musical approaches too. In Bulgaria, Yugoslavia, Romania and Albania, the new regimes had as a common denominator the leading role of the state, which, of course, had not the same intensity in all the countries and all over the years. Both folklore research and the let's say "commercial" discography were called to get in tune with 
the government sense of the proper and the beautiful, which frequently included a self-complacent praise of the government achievements and an imposed optimism. The reconstruction of economy, sometimes including even forced displacements of populations, radically changed the framework and the mechanism of production and dissemination of folk songs; this way, they gave birth to a totally new genre (Rice, 1994, 169-233). A very basic feature of this new genre was teamwork; large orchestras, large choirs, and consequently a need for accuracy, in tune and in rhythm as well. Folk instruments, and the folk musician along them, were quickly turned into national symbols, their teaching became institutionalized and the level of folk musicians, through the systematic education, skyrocketed. Virtuosity, in some cases totally astonishing, is a second feature of this new genre, and can be observed even in small groups based on tradition, like the well-known Trio Bulgarka.

These new conditions transform, first and foremost, gajdas. Having to participate in larger ensembles, they had to align with the widely accepted tuning, in terms of both construction and performing practice. Commonly accepted practices were widely applied, as these ensembles were recruited from wider regions and not only from a single village, where they would play with "their own" percussionist, as it was the case in the past. These new conditions allowed, or they led to the formation of even larger ensembles, the most extremes of which, till today, is rather the 100 Kaba Gajdi of Rhodope.

Zurna was less affected by this "orchestralization". Possibly one reason was the powerful sound of the zurna, making it less adaptive in chamber orchestras but possibly the main reason was its association with Roma musicians, that were not very well accepted in the national narratives. I would mention that, on the contrary, tapan was better assimilated, with the use of electronic balancing of the sound or with addition in larger ensembles.

It's rather surprising that in Albania and Romania, both gajdas and zurnas practically disappear after Second World War. One more possible question is whether the promotion of the gajda as a Slavic national symbol, especially in Bulgaria, made it politically unwanted in the other countries. Anyway, its use was already restricted.

On the other side, in Greece things didn't change a lot in terms of regime and of economic structures. Attempts of greekification (or removal) of Slavic speaking population went on, and I must note that the Greek civil war that followed Second World War included also the ethnic cleansing of Slavic speaking people. Gajda in Greek Macedonia and Thrace became a clearly unwanted symbol for the state mechanisms, and there are even stories about policemen destroying instruments, but I can't tell if they were following instructions or if it was their excessive zeal. Recordings of gajdas and zurnas appear timidly in a liminal commercial discography (from the Domna Samiou collection) in the late 1960's; one must note that these gajdas came from the islands (Kalymnos, Karpathos, later Crete), where there was no question of Slavic languages. The first sample from northern Greece appeared in the 1970's, in more ethnographic albums from the Simon Karas and the Dora Stratou collections, while after 1975 there appeared some clearly commercial albums with zurna only. I want to mention here the album Ballos by Dionysis 
Savvopoulos (Savvopoulos, 1971), a "progressive rock" album of 1971, where a gajda from Thrace has a leading role in some parts. Very probably this is the first appearance of north Greek gajda on record.

It was a period where things seemed to change, as there was a change of political circumstances in the country as well. It was a period with steps towards reconciliation in general. Of course, references to Slavic languages are avoided, song words are omitted or translated, but from time to time some Slavic title or term drops in - baidushka, liaskoviki, rougatsariko etc. - possibly due to folklorists' ignorance. Anogianakis, in his monumental book, in 1976, devotes a significant portion on gajdas. In general, there is an attempt to connect gajdas to an earlier past, with less ethnic tensions, an era where gajda was widely used in the Greek territory, as it becomes clear from references in paintings or in literature (Anogianakis, 1991, 154). As a part of democratization of the era, there is an increase of public interest about "people's" music, in contrast to the earlier interest about what was considered "national".

But after all these, as gajdas have been "invisible" in Greece for decades and only in the late 1970's come to some wider recognition, it's not strange that they sound much more primitive compared to the ones of the northern neighbors; there was no demand out of the limits of each village, no effort to combine them with other musical elements. That's exactly why there is such a striking difference between the two sides of the borders. In the 1980's, as there were even greater steps towards democratization and ideas as locality and cultural diversity started spreading all over Greece, things changed to better. After the collapse of the Eastern Block and the gradual political unification of Europe, the situation came back closer to normal life. The situation for zurna was rather similar, as it was an instrument associated with Roma population, which was officially considered by the state as "foreigners of unknown nationality" till 1970 (Bandelas, 2015, 14).

4.

Concluding, I would like to put three more general questions. If, in fifty years (or possibly less) since the introduction of the clarinet, gajda and zurna disappear totally from regions like Thessaly or Epirus, or from whole countries like Romania and Albania, then, how can we think that the traditions keep stable for centuries? A similar question must be pointed to the influence of governmental regimes. Performing arts, residing mainly in the sphere of orality, are extremely volatile and disappear, leaving no traces. Next question, maybe the role of folklorists is equally influential for the formation of traditions, as the record industry and the state media? The folklorist, by deciding on what must be called "tradition", finally he shapes it, up to the point of constructing it. Finally, summing up all the above, I want to question whether, all these that we call "old traditions" still sound somehow close to what they used to, one hundred years ago. And as John Cage used to say, "This is a very good question; I don't want to spoil it with an answer". 


\section{LITERATURE}

AHMEDAYA, A. (2012). Discovering Albania. Tirane: Ulysseus Foundation (CD). ANDERSON, B. (2006 [1983]). Imagined communities. Reflections on the Origin and Spread of Nationalism. London, New York: Verso.

ANOGIANAKIS, F. (1991 [1976]). Greek Folk Musical Instruments. Athens: Melissa.

BANDELAS, V. (2015). "Introduction" in Vandelas \& Drygianakis (eds.) I tsiaisilouloudi, Songs of the Greek Roma from Sofades, Karditsa. Volos: Volos Academy Publications.

BOHLMANN, P. (1988). The Study of Folk Music in the Modern World. Indiana: Indiana University press.

CLIFFORD, J. (1997). Routes: Travel and Translation in the Late Twentieth Century. Cam-bridge, MA: Harvard University Press.

DELTSOU, E. (1995). Praxes of Tradition and Modernity in a village in Northern Greece, $\mathrm{PhD}$ Thesis, Indiana University (unpublished). Available at:

https://www.academia.edu/

2371037/Praxes_of_Tradition_and_Modernity_in_a_Village_in_Northern_Greece (accessed Jan. 30, 2020).

DIVANI, L. (1995). Greece and Minorities. Athens: Kastaniotis.

DRAGOUMIS, M. (ed.) (1976). Folk songs from the Melpo Merlier collection. Athens: Polygram (LP record, republished as a CD in 1996).

DRAGOUMIS, M. (ed.) (2003). Songs of Pontos, Recordings of 1930. Athens: Musical Folklore Archives (CD).

EMPEIRIKOSL. et al.(2001). (Research Center for Minority Groups): Linguistic Otherness in Greece. Athens: Alexandria.

HERZFELD, M. (1982). Ours Once More: Folklore, Ideology and the Making of Modern Greece. Austin, TX, University of Texas press.

KOSTOPOULOS, T. (2008). The Forbidden Language: State suppression of Slavic dialects in Greek Macedonia. Athens: Vivliorama.

LIAPIS, K. (1994). The "great" Ai-Yiorgis of Pelion. Volos: Ores.

MAZARAKI, D. (1984 [1959]). Folk Clarinet in Greece. Athens: Kedros.

RICE, T. (1994). May it fill your soul. Experiencing Bulgarian music. Chicago: University of Chicago Press.

ROUDOMETOF, V. (1998). From Rum Millet to Greek Nation: Enlightenment, Secularization, and National Identity in Ottoman Balkan Society, 1453-1821. Journal of Modern Greek Studies, Volume 16, 1998.

SAVVOPOULOS, D. (1971). Ballos. Athens: Lyra (LP).

STERNE, J. (2003). The audible past: Cultural origins of sound reproduction. Durham: Duke University Press. 
Костис Дригианакис

\section{РАЗВОЈОТ И РАЗЛИКИТЕ НА ГАЈДАТА И ЗУРНАТА ВО БАЛКАНСКИТЕ ЗЕМЈИ}

\section{Резиме}

Во овој текст се претставени присутноста и разликите во развојниот пат на два музички инструменти (гајдата и зурната) застапени во различни балкански земји, како и нивната присутност во музичките записи и дискографијата. Од досегашните анализи може да се заклучи дека зурната, но и гајдата, сѐ уште се негуваат во регионите каде што било невозможно да се заменат како музички инструменти, но постојат и региони каде што овие инструменти комплетно исчезнуваат како воопшто и да не биле присутни. Во некои региони, инструментиве поседуваат префинет звук, прецизност во штимањето и ритамот (како на пример во Бугарија), додека пак, во некои региони го зачувале оној специфичен нерафиниран звук од далечното минато (како на пример во Грција).

Од музичките анализи може да се заклучи дека звучните записи не секогаш се доволно репрезентативни примери за тоа како звучи народната музичка традиција во руралните средини како нејзина природна средина и културен контекст каде што автентично била негувана. Од музичките записи, исто така, може да се забележи дека постои дистинкција во целите за кои тие се снимени и ставени на носач на звук. Дистинкцијата се согледува во записите кои се направени со цел да бидат покомерцијални и подостапни до пошироката публика, и во записите кои се направени со цел да се зачува автентичноста на некогашната народна музичка традиција и да послужи за некои идни етномузиколошки истражувања и анализи. 